\title{
Tanggung Jawab Orang Tua terhadap Pendidikan Akhlak Anak dalam Perspektif Al-Qur'an
}

\section{Achmad Junaedi Sitika dan Ine Nirmala \\ Universitas Singaperbangsa Karawang \\ Email: achmad.junaedi@staff.unsika.ac.id}

\begin{abstract}
Parent is the first teacher for children that should have designed the pattern and methods of parenting in educating their children, since waiting for the birth of a child, even before marriage. This research is motivated by a big challenge in educating children today which is so influenced by fast and many information that can exert a bad influence created by the environment of modernity that lacks religious values. The purpose of this study is to know the responsibility of parents in moral education of children based on Al-Quran, At-Tahrim verse 6 . Using qualitative methods, searching and collecting data through library research. Responsibility of parent in moral education of children based on Al-Qur'an, At-Tahrim verse: 6 that is the importance of obedience to Allah, always remembering Him in zikr, and forbid children from disgraceful acts, by with educating and teaching the children about tauhid and moral valuess, especially educating how to perform and establish prayers, because with prayers, it can prevent people from a bad and worst behaviour.
\end{abstract}

Keywords: early chilhdhood education, prophetic education, Al-Qur'an perspective 


\section{PENDAHULUAN}

Sudah menjadi aksioma bahwa orang tua bertanggungjawab terhadap pendidikan anak. Orang tua adalah guru pertama bagi anak sudah seyogyanya sejak menanti kelahiran anak, bahkan sebelum menikah, calon orang tua telah merancang bagaimana pola asuh dan metode mendidik anak-anaknya. "Anak adalah nikmat Allah SWT yang tak ternilai dan pemberian yang tak terhingga." Webersis (2008: 2) Tidak ada yang lebih tahu besarnya karunia ini selain orang yang tidak atau belum memiliki anak. Nikmat yang agung ini merupakan amanah bagi kedua orang tuanya yang kelak akan dipertanggungjawabankan, apakah keduanya telah menjaga atau justru menyia-nyiakannya. Rasulullah SAW bersabda: "Setiap kalian adalah pemimpin, dan setiap kalian akan ditanya tentang kepemimpinannya. Seorang imam adalah pemimpin dan dia akan ditanya tentang kepemimpinannya dan seorang laki-laki adalah pemimpin dalam keluarganya dan dia ditanya akan kepemimpinannya". (H.R Muttafaq 'alihi). (Mukhtar Al Hadist Al Nabawiyah, hal 112)

Selanjutnya orang tua yang mempunyai tanggung jawab penuh terhadap tumbuh kembang buah hatinya hingga mengantarnya ke gerbang kedewasaan dengan mampu berpikir, bertindak dan bertanggungjawab terhadap dirinya sendiri, masyarakat/lingkungan dan terhadap Tuhan Yang Maha Esa. Pada dasarnya tujuan pokok dalam mendidik anak adalah untuk menumbuhkan dan membangkitkan jiwa kehambaan dalam diri mereka, menyiramkan dalam jiwa mereka dan senantiasa membiasakan sikap tersebut. Merupakan nikmat Allah adalah mereka diciptakan dalam fitrah Islam. Tugas kita hanya menjaga, mengontrol dan memperhatikan agar tidak menyimpang dari fitrahnya.

Yadi Purwanto (2007: 2-3). Mendidik anak di jaman modern ini tidaklah mudah, di satu sisi jaman ini memberikan berbagai banyak kemajuan teknologi yang memungkinkan anak-anak kita memperoleh fasilitas yang serba "canggih" dan "wah". Anak-anak sekarang sejak dini sudah mengenal handphone, camera dan berbagai peralatan yang amat modern/ gadget. Kemajuan yang demikian cepat juga ditenggarai membawa dampak negatif seperti tersedianya informasi negatif melalui media massa yang sulit untuk dihindari, misalnya; pornografi, kekerasan, consumer-isme, takhayul, klenik, dan kemusyrikan melalui berbagai media informasi seperti internet, handphone, majalah, televisi dan juga VCD. 
Berbagai kenyataan modernitas dan ketersediaan tersebut faktanya tidak sulit bahkan setiap hari disediakan baik oleh keluarga, masyarakat, dan juga dunia informasi. Maraknya dunia periklanan memaksa informasi beredar lebih mudah dan juga lebih merangsang rasa ingin tahu, rasa ingin mencoba sebagai akibat "rayuan maut" publikasi yang memang dirancang secara apik oleh para ahli komunikasi dengan biaya yang mahal dan dengan dampak meluas dan mendalam dapat dikatakan informasi-informasi tersebut dapat lebih cepat hadir daripada sarapan pagi kita, atau lebih cepat disantap daripada nasehat orang tua.

Merupakan tantangan terbesar dalam pendidikan anak jaman sekarang adalah informasi yang rusak dan pengaruh buruk yang diciptakan oleh lingkungan modernitas yang tidak berbasis agama. Tugas berat para orang tua adalah menyakinkan fungsi keluarga mereka benar-benar aman, nyaman bagi anak-anak mereka. Rumah adalah surga bagi anak, yang mana mereka dapat menjadi cerdas, sholeh, dan tentu saja tercukupi lahir dan batinnya. Padahal mana ada surga yang dibangun di atas keserba kekurangan iman, ilmu, dan amal sholeh.

Anak didik di dalam mencari nilai-nilai hidup harus dapat bimbingan sepenuhnya dari pendidik atau orang tua, yaitu ayah dan ibu, "Karena menurut agama Islam, saat anak dilahirkan dalam keadaan lemah dan suci sedangkan alam sekitarnya akan memberi corak warna terhadap nilai hidup atas pendidikan agama anak didik." (Zuhairini 1993: 170). Hal ini sebagaimana sabda nabi Muhammad SAW yang berbunyi: "Tidaklah anak yang dilahirkan itu kecuali telah membawa fitrah (kecenderungan untuk percaya kepada Allah), maka kedua orang tuanyalah yang menjadikan anak tersebut beragama Yahudi, Nasroni, dan Majusi." (H.R Muslim) (Mukhtar Al Hadist Al Nabawiyah, hal 134).

Penelitian ini bertujuan untuk mengetahui tanggung jawab orang tua terhadap pendidikan akhlak anak berdasarkan AlQuran surat At-Tahrim ayat 6 .

\section{DISKUSI}

\section{Tanggung jawab Orang Tua}

Tanggung jawab pertama dan utama di lingkungan keluarga terletak pada orang tua. Tanggung jawab orang tua adalah 
keadaan wajib menanggung segala sesuatunya (mendidik, mengajarkan dan memberikan nafkah) baik secara lahiriah dan bathiniyah kepada Allah SWT, guna mewujudkan suasana keluarga yang harmonis dan sejahtera. Dengan demikian, tanggung jawab orang tua berkewajiban memberikan pendidikan jasmani (lahiriah) maupun pendidikan rohani (bathiniyah) (Zainuddin 1994: 28) pendidikan jasmani (lahiriah) adalah ajaran yang diberikan agar anak bisa merawat dirinya, sehingga dia bisa tetap hidup sehat, segar dan tumbuh sebagaimana mestinya, ia harus tumbuh, terhindar dari segala kekurangan, penyakit maupun suatu perbuatan yang merugikan atas pertumbuhan badan secara alami. Sedangkan pendidikan rohani (bathiniyah) adalah pendidikan jiwa, agar anak mempunyai jiwa yang kuat dan sehat. Perlu adanya pendidikan rohani, keagamaan dan memberikan kebutuhan biologis lainnya, seperti kasih sayang, makan, minum, pakaian, perlindungan dan sebagainya.

Di samping mempunyai berbagai kewajiban terhadap anakanaknya, orang tua diharapkan dan sangat diharuskan bahwa orang tua harus memperhatikan dalam bidang keagamaan atau tanggungjawab kepada Allah SWT, karena keluarga atau orang tua dan fungsi-fungsinya itu merupakan pelaksanaan amanat Allah SWT (Taqiyuddin, 2008: 92). Pandangan ini mengacu kepada firman Allah SWT yang terdapat pada AI Qur'an surat At Tahrim ayat 6 :

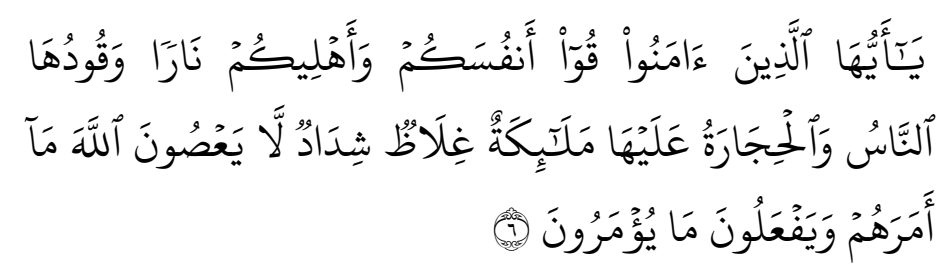

Artinya: "Hai orang-orang yang beriman, peliharalah dirimu dan keluargamu dari api neraka yang bahan bakarnya adalah manusia dan batu; penjaganya malaikat-malaikat yang kasar, yang keras, dan tidak mendurhakai Allah terhadap apa yang diperintahkan-Nya kepada mereka dan selalu mengerjakan apa yang diperintahkan." (Q.S At Tahrim, 6)

Dari ayat di atas, ini menunjukkan kewajiban orang tua untuk memelihara diri dan keluarganya (istri dan anak) agar terpelihara dari perbuatan tercela, perilaku yang baik. Tugas ini harus diiringi dengan mengisi jiwa anak dengan keimanan dan ketaqwaan kepada Tuhan Yang Maha Kuasa, dan berbudi 
pekerti, baik kepada sesama umat manusia. (Arsyad Ahmad, 2007: 63).

Anak dihadirkan sebagai cobaan bagi setiap orang tua, yang berupa suatu cobaan hidup dengan cara menambah beban tanggung jawab. Tanggung jawab itu sendiri berupa "Tanggung jawab untuk merawat dan tanggung jawab untuk mendidik" (Zainudin, 1994: 2). Untuk memperjelas dari kedua faktor di atas, uraiannya sebagai berikut :

\section{Tanggung Jawab Untuk Merawat}

Orang tua diwajibkan untuk merawat anak-anaknya. Perawatan ini bisa berupa perlindungan. Orang tua harus memeberi perlindungan terhadap anaknya dari sengatan panas matahari dan atau hawa dingin di malam hari. Memberi perlindungan kesehatan, yang artinya mengusahakan agar anak dalam keadaan tetap sehat, terhindar dari rasa lapar dan memberi dukungan terhadap segala sesuatunya untuk kelangsungan hidup dlam rumah tangga. Dan tentunya kini orang tua telah mengerti dan sadar akan pentingnya perawatan anaknya. Memang pada umumnya pertumbuhan anak, baik watak, mental maupun fisiknya banyak dipengaruhi oleh budaya masyarakat, kebiasaan keluarga maupun perkembangan yang terjadi di dalam masyarakat itu sendiri. Dengan demikian menurut kesadaran orang tua secara penuh dan bertanggung jawab atas segala perkembangan yang terjadi pada anaknya. Kemudian diajarkan pula tentang sangsisangsi apa yang harus diterimanya bila ia melakukan tidakantindakan yang di anggap sebagai larangan oleh Agama. (Zainudin, 1994: 35).

\section{Tanggung Jawab Untuk Mendidik}

Mendidik adalah memeberi latihan dan memelihara, ajaran, bimbingan mengenai akhlak dan kecerdasan fikiran. (Fahmi Idrus, Hal 171). Yang lainpun mengatakan, mendidik adalah membimbing anak untuk mencapai kedewasaan (Syafei, 2006: 2). Membingbing atau bimbingan diartikan sebagai "Proses untuk membantu anak unutuk mengenal dirinya sendiri dan dunianya" (Ditjen Dikdasmen Depdikbud, 1928: 23). Dengan begitu, dapat dipahami bahwa dalam mendidik itu apa yang dilakukan oleh orang yang mendidik, dalam hal ini orang tua, sebatas dalam bentuk pemberitahuan. Pada dasarnya, anak itu sendiri telah memiliki potensi dan 
kemampuan untuk menuju kedewasaannya. Mendidik merupakan usaha memerikan tuntutan kepada anak didik untuk berdiri dengan norma-norma kemanusiaan yang sesuai dengan kepribadian bangsa, yakni Pancasila (Sardiman, 2004: 54). Dalam rangka mengimbangi perkembangan zaman ini, maka manusia yang hidup didalammnya harus canggih pula, terutama bagi orang tua yang ahrus mendidik kecerdasan kreativitias dan mendidik kecerdasan moral, agar anak siap menghadapi masa depan.

\section{Peranan Orang Tua Dalam Pendidikan Akhlak Anak}

Memasuki abad ke 21 ini mulai terjadi berbagai perubahan yang sangat mendasar tentang pola asuh anak dalam keluarga, padahal sebelumnya lebih cenderung kepada pola asuh tunggal. Di era modern sekarang ini, penetrasi media masa dan acuan globalisasi dengan begitu cepat dan pesat memasuki dinding kamar rumah dan menemani anggota keluarga di rumah sepanjang waktu, ketika waktu kebersamaan orang tua berkurang karena tuntutan kesibukan. Orang tua dapat memberikan suatu program pendidikan di rumah yang akan meningkatkan kualitas penggunaan waktu kebersamaan orang tua dengan anaknya" (Arsyad Ahmad, 2007: 30).

Lebih lanjut bahwa dalam menghadapi itu orang tua seyogyanya sudah harus mengambil "peranan" yang strategis yang tidak bisa dilakukan oleh orang atau lembaga lain seperti media masa, sebaliknya ia sudah harus memposisikan diri sebagai "educator (pendidik), motivator (pendorong) dan selector (penyaring informasi)" (Marwah Dawud, 1994: 207).

Secara umum peranan orang tua dalam pendidikan akhlak anak adalah "untuk membangun keluarga sakinah, yang mengharapkan keturunannya menjadi anak-anak yang shalih dan shalihah, yang ingin mewujudkan ketentraman dan ketenangan secara psikologis, yang ingin mewujudkan sunnah Rasulullah SAW dengan berketurunan dan memenuhi kebutuhan terhadap cinta dan kasih antara lawan jenis" (Abdurrachman An-Nahlawi, 1995: 139-141).

Orang tua seyogyanya mampu penampilan sikap saling menghormati, saling menolong, berkomunikasi dengan penuh tatakrama dan penuh keakraban, bersikap jujur dan tegas, mampu memecahkan masalah anaknya serta penyaluran minat dan pergaulan yang baik juga menanamkan 
kepercayaan diri, kesemua sikap ini akan membekas dan terkesan pada jiwa anak, karena itu, faktor konsistensi dari semua sikap itu adalah sangat menentukan.

Orang tua dengan anak-anak yang memiliki Selfesteem (harga diri) positif juga cenderung menunjukkan diri yang tinggi juga, anak-anak belajar dari mereka cara menghadapi kesulitan dan tantangan, mereka membuka diri terhadap penilaian anakanaknya. Menjelaskan kelebihan dan kekurangan mereka secara rasional. Orang tua harus memperhatikan kebutuhan anak-anaknya dan harus sangat akrab terhadap anak-anaknya. Orang tua yang otoritatif (berkuasa/patuh) yang mampu menanamkan selfesteem yang tinggi pada anak-anaknya. Anak-anak pada gilirannya memiliki perasaan mampu untuk menghadapi berbagai kesulitan. Mereka lebih berhasil belajar ketimbang rata-rata anak-anak dari orang tua otoritarian (patuh kepada seorang) dan permisif (keinginan seorang anak) (Jalaluddin Rachmat, 1997: 345-347).

Peranan orang tua dalam pendidikan anak, tentunya orang tua harus mempunyai langkah-langkah dan metode-metode yang tepat dengan tujuan, agar anaknya tumbuh dan berkembang menuju kedewasaan dengan beriman dan bertaqwa kepada Allah SWT. Metode - metode dan langkah-langkah yang harus diberikan oleh orang tua pada pendidikan anak menurut Ahmad (2007: 56-60) adalah:

1. Metode Otoriter adalah melatih anak untuk mengikuti suatu standar/harapan dari mereka yang berkuasa. Metode otoriter biasanya diikuti suatu hukuman atau ancaman.

2. Metode Demokratik adalah menekankan pada aspek pendidikan logika, di dalamnya terdapat kompromi dengan membiarkan anak menilai suatu peraturan atau tindakan yang diperkenalkan kepadanya, ketika ia menyatakan ketidaksetujuannya terhadap aturan tersebut, ia diberi kesempatan untuk mengemukakan alasannya. Jika alasannya dianggap logis dan benar, maka perubahan terhadap peraturan sangatlah mungkin dilakukan.

3. Metode Permisif adalah membiarkan anak untuk bertindak sesuai dengan keinginannya. Anak belajar dari perilakunya sendiri berdasarkan akibat yang mereka rasakan. Misalnya anak berlari-lari di halaman rumah, karena tidak hati-hati, akhirnya terjatuh, maka mereka belajar dari 
pengalamannya itu sehingga pada kesempatan lain mereka lebih berhati-hati ketika berlari.

\section{Pendidikan akhlak anak}

Akhlak merupakan cermin dari iman yang mencakup dalam segala bentuk prilaku. Pendidikan akhlak yang harus diberikan pada anak-anak sejak dini agar mereka kelak menjadi manusia yang diridhoi oleh Allah SWT dan dapat menghargai semua orang. Pendidikan itu sangat penting dalam tindakan-tindakan akhlaknya dalam kehidupan sehari-hari, karena pendidikan itu adalah "Proses pengubahan sikap dan tingkah laku seseorang atau kelompok orang dalam usaha mendewasakan manusia melaui upaya pengajaran, dan pelatihan proses perbuatan cara mendidik" (Fahmi Idrus: 171). Sedangkan akhlak itu sendiri adalah suatu keadaan yang melekat pada jiwa manusia-manusia, yang daripadanya lahir perbuatanperbuatan dengan mudah, tanpa melalui proses pemikiran (Syahlan Sayfei, 2006: 76).

Akhlak adalah "Suatu pendidikan yang mengajrakan tentang nilai-nilai kemanusiaan, atau ajaran tentang baik dan buruk" (Zainuddin, 1994: 90). Menurut kamus besar Bahasa Indonesia Akhlak adlah "Tabiat, watak, budi pekerti dan moral" (Fahmi Idrus, Hal 22). Dari uaraian tentang pendidikan dan akhlak di atas menurut para ahli, maka kesimpulan pendidikan akhlak adalah proses pembinaan budi pekerti anak sehingga menajdi budi pekerti yang mulia (Akhlakul karimah). Dalam hal pendidikan akhlak, orang tua sangat berperan dalam memberikan pendidikan agama secara menyeluruh, selain itu akhlak anak bergantung pada kebiasaan dan prilaku orang tua dan saudara-saudaranya di rumah, anak-anak akan mencontoh prilaku ayah dan ibunya dalam berprilaku. Anakanak akan meniru kebiasaan dan tingkah laku orang tua dan saudara-saudaranya. Oleh karena itu, sudah semestinya "orang tua dapat menjadi contoh teladan bagi anak-anaknya" (Agus Syafi'i, 2009: 1).

Contoh teladan bagi anak-anak misalnya sopan santun dalam bertutur maupun berprilaku sehari-hari. Dalam mengajarkan pendidikan di rumah, orang tua dapat mengajarkan dari hal-hal yang kecil terlebih dahulu seperti berbakti pada orang tua, sopan keapda orang tua, saudara-saudara dan lain sebagainya. Pendidikan anak untuk menjadi insan mulia tentunya didasarkan kepada akhlak, bahwa akhlak menempati posisi yang santa petnting dan strategis dalam kehidupan 
umat manusia di dunia ini. Akhlak sangat penting dalam kehidupan bermasyarakat, berbangsa, bernegara, berkeluarga dan dalam individu anak manusia. oleh karenanya, setiap aspek dari kehidupan ini harus diorientasikan pada pembentukan dan pembinaan akhlak yang baik, akhlak yang terpuji atau akhlak mulia. Tentunya orang tua sudah pasti menginginkan anaknya berakhlak mulia, maka orang tua harus ikut mendidik anak berakhlak mulia. Akhlak mulia terhadap Tuhan, terhadap orang tua, terhadap guru, terhadap saudara, terhadap teman, terhadap tetangga dalam bentuk perkataan, perbuatan, sikap, penampilan pakaian, dalam keluarga, ditempat kerja dan akhlak mulia di tempat umum" (Syahlan Syafe'i, 2006: 78-79).

\section{Tanggung Jawab Orang Tua Terhadap Pendidikan Akhlak Anak Berdasarkan Al - Qur'an Surat At-Tahrim ayat 6.}

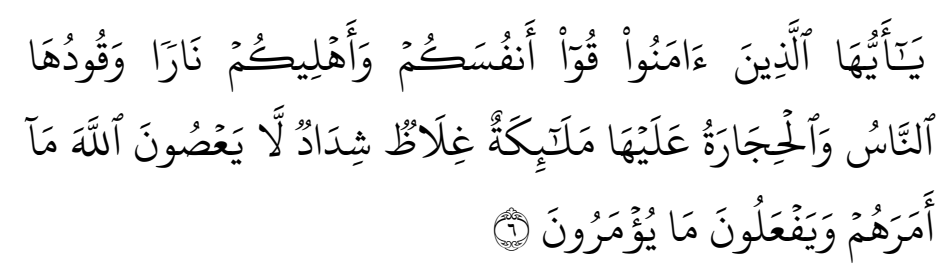

Artinya : "Hai orang-orang yang beriman, peliharalah dirimu dan keluargamu dari api neraka yang bahan bakarnya adalah manusia dan batu; penjaganya malaikat-malaikat yang kasar, keras, dan tidak mendurhakai Allah terhadap apa yang diperintahkan-Nya kepada mereka dan selalu mengerjakan apa yang diperintahkan." (At-Tahrim: 6)

Ayat di atas menyiratkan bahwa tanggungjawab orang tua dalam pendidikan akhlak anak yang sangat penting sekali adalah anak diajarkan hal-hal yang telah difardukan Allah SWT dan sesuatu hal yang harus di jauhi sebagaimana Allah telah melarangnya, Ad-Dhahak dan Muqotil telah menafsirkan dari ayat-ayat di atas, "Bahwa sudah merupakan suatu kewajiban bagi seseorang Muslim mengajarkan kepada keluarganya, baik dari kalangan kerabatnya ataupun budak-budaknya, halhal yang difardukan oleh Allah dan mengajarkan kepada mereka hal-hal yang dilarang oleh Allah yang harus mereka jauhi." (Abul Fida Ismail Ibnu Katsir Ad Dimasqi, 2008: 416).

Hal-hal yang difardukan oleh Allah yang harus dilaksanakan dan hukumnya wajib yaitu kewajiban melaksanakan dan mendirikan shalat, semakna dengan ayat ini firman Allah yaitu QS. Thaaha: 132: 


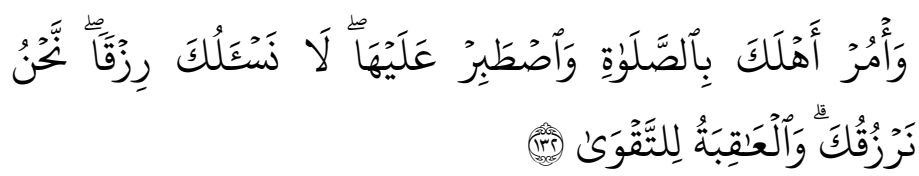

Artinya: "Dan perintahkanlah kepada keluargamu mendirikan shalat dan bersabarlah kamu dalam mengerjakannya. Kami tidak meminta rezeki kepadamu, Kamilah yang memberi rezeki kepadamu. Dan akibat (yang baik) itu adalah bagi orang yang bertakwa." (QS. Thaaha: 132)

Dan dijelaskan pula dengan firman-Nya QS. As-Syu'araa: 124

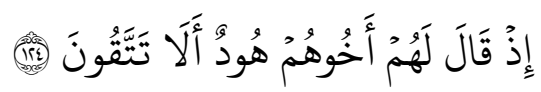

Artinya: "Ketika saudara mereka, Hud, berkata kepada mereka: "Mengapa kamu tidak bertakwa?"

Semakna dengan ayat ini adalah hadits yang diriwayatkan oleh Samurah Bin Jubdab, berkata nabi SAW bersabda: "Perintahkanlah anak untuk Shalat jika dai sudah mencapai usia tujuh tahun. Apabila dia sudah mencapai sepuluh tahun pukullah dia karena meninggalkan Shalat." (HR Abu Daud)

Hadits di atas, redaksi hadits ini milik Abu Daud, menurut hadits At-Thabari (Imam Al-Qurthubi, 2009: 747) tetapi dalam tafsir Ibnu Katsir hadits di atas diriwayatkan oleh Imam Ahmad, Imam Abu Daud dan Imam Turmuzi melalui hadits Abdul Malik Ibnu Sabrah, dari ayahnya, ayahnya dari kakeknya. (Abul Fida Ismail/Ibnu Katsir Ad Dimasyai, 2008: 416). Imam Turmudzi menyatakan bahwa hadits ini hasan tidak dlo'if.

Hal yang semisal, sudah barang tentu orang tua mendidika akhlak anaknya apa yang di fardukan Allah, dan sebagian hal yang di fardukan Allah yaitu Puasa, ulama Fiqih menayatakan bahwa hal yang sama diberlakukan terhadap anaknya adalah "dalam masalah puasa" (Abul Fida Ismal Ibnu Katsir, 2008: 416). Agar hal tersebut menjadi latihan bagian dalam ibadah, dan bila ia sampai usia baligh sudah terbiasa untuk mengerjakan ibadah, ketaatan dan menjauhi maksiat serta meninggalkan perkara munkar. Dengan demikian bahwa shalat itu mencegah dari perbuatan keji dan munkar, dan sebagi tujuan agama, karena itulah orang tua harus sungguhsungguh semaksimal mungkin mendidik dan mengajar anaknya dal hal ihwal agama, terutama Shalat.

Nabi bersabda: "Shalat itu adalah tiangnya agama maka barang siapa yang mengerjakan sungguh dia telah mendirikan 
agamanya dan barang siapa yang meninggalkannya sungguh telah merobohkan agamanya."

Semakna dengan Firman Allah SWT QS. AI-Ankabut: 45

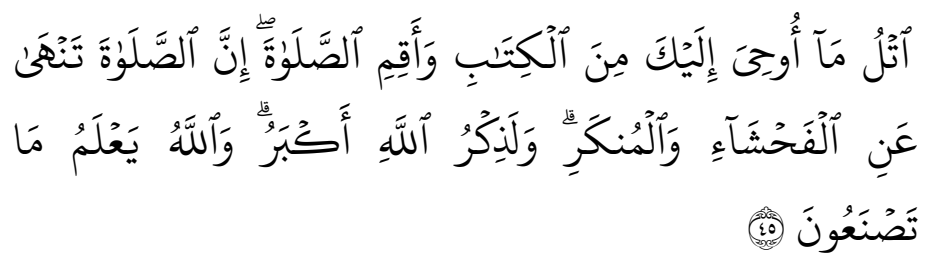

Artinya : Bacalah apa yang telah diwahyukan kepadamu, yaitu Al Kitab (Al Quran) dan dirikanlah shalat. Sesungguhnya shalat itu mencegah dari (perbuatan-perbuatan) keji dan mungkar. Dan sesungguhnya mengingat Allah (shalat) adalah lebih besar (keutamaannya dari ibadat-ibadat yang lain). Dan Allah mengetahui apa yang kamu kerjakan

Maka dengan memerintahkan sholat terhadap keluarganya dan memerintahkan yang Allah Fardukan terhadap yang lainnya sungguh orang tua telah menjaga dari api neraka atau azab Allah "Jagalah keluarga kalian dari azab Allah itu sebagaiman kalian menjaga diri kalian sendiri darinya." (A'idh Al - Qarni, 2008 : 371). Orang tua pun bukan hanya mengajari anaknya untuk melakukan shalat dan fardhu-fardhu yang lainnya, juga harus mendidik anaknya sesuatu hal yang haram, karena tidak sangat mencerminkan, shalat dilaksanakan dan yang haram masih dikerjakan, ini semua sesuatu yang tidak diinginkan karena masih bercampur dengan perbuatan yang tidak diridhoi Allah (perbuatan yang haram). Maka dengan demikian "Seseorang harus mengajari maknanya sesuatu yang halal dan yang haram, sekaligus menjauhkannya dari kemaksiatan dan dosa, serta hukum-hukum yang lainnya." (Imam AlQurtubi, 2009 : 746).

Maka dari itu, "seseorang harus memperbaiki dirinya sendiri dengan melakukan ketaatan, dan juga memperbaiki keluarganya layaknya seorang pemimpin memperbaiki orang yang dipimpinnya." (Imam Al-Qurtubi, 2009: 745) dan tentunya selalu menjadi orang tua yang beriman harus menjadi contoh bagi keluarga atau anaknya sebagai penghalang dari api neraka. "Wahai prang-orang mukmin, adakanlah penghalang antara diri kalian dari azab Allah, yakni dengan cara memerintahkan mereka untuk menaati Allah dan meninggalkan maksiat terhadap Allah." ('Aidh Al-Qarni, 2008: 371). 
Dari uraian-uraian di atas, jelaslah orang tua mempunyai peranan dan tanggung jawab yang harus dipenuhi dan memelihara anaknya, jika orang tua tidak bertanggung jawab, tidak memelihara anaknya dan tidak membawa keluargamu kepada hal itu dengan nasehat dan pelajaran maka dengan kemungkinan, dalam kehidupan keluarga tidak akan mendapatkan kebahagiaan dan keselamatan, dan sungguh Allah akan memberikan azab, berarti dia (orang tua) termasuk orang-orang yang zalim. Hati-hatilah terhadap api neraka yang bahan bakarnya dari oranf-orang kafir dan batu-batuan, yang jaganya adalah malaikat-malaikat Allah yang sangat kuat dan bengis. Firman Allah SWT QS. At-Tahrim: 6

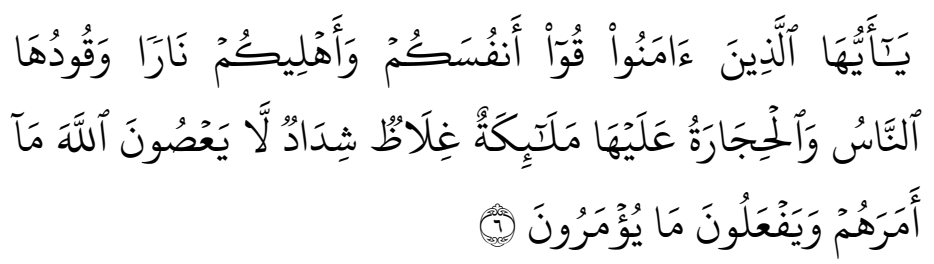

Artinya : "Hai orang-orang yang beriman, peliharalah dirimu dan keluargamu dari api neraka yang bahan bakarnya adalah manusia dan batu; penjaganya malaikat-malaikat yang kasar, keras, dan tidak mendurhakai Allah terhadap apa yang diperintahkan-Nya kepada mereka dan selalu mengerjakan apa yang diperintahkan". (At-Tahrim: 6)

Maksudnya adalah "Malaikat Zabaniyah yang keras hatinya, keras tubuhnya, keras ucapannya, keras pula perbuatannya dan kasar dalam menghukum penghuni neraka." (Imam AlQurtubi, 2009: 750). Di tafsir lain "para Malaikat Allah sangat kuat dan bengis" ("Aidh Al-Qarni, 2008: 751) dan tafsir lain pula berpendapat "Para penjaga neraka yang kasat hatinya dan tidak mau mengasihi apabila mereka diminta belas kasiha" (Ahmad Mustafa Al Maraghi, 1993: 260). Mereka (Malaikat) tidak pernah melanggar larangan-Nya, para Malaikat penajaga Neraka itu senantiasa dan tidak pernah bermaksiat terhadap Allah.

Firman Allah SWT QS At-Tahrim: 6

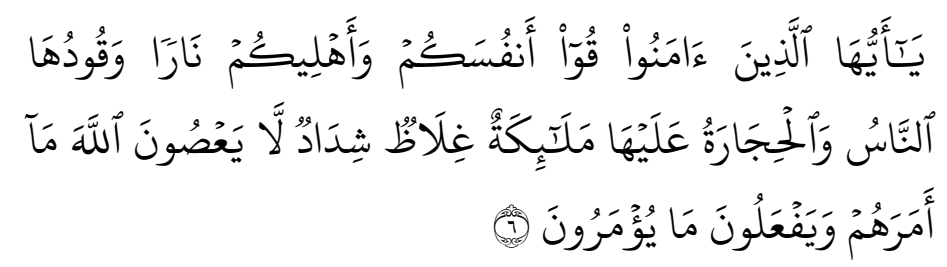


Artinya: "Hai orang-orang yang beriman, peliharalah dirimu dan keluargamu dari api neraka yang bahan bakarnya adalah manusia dan batu; penjaganya malaikat-malaikat yang kasar, keras, dan tidak mendurhakai Allah terhadap apa yang diperintahkan-Nya kepada mereka dan selalu mengerjakan apa yang diperintahkan".

Dalam tafsir Ibnu Katsir, Tafsir Almaraghi, Tafisr Al Qurtubi, Tafsir Jalalainda, Tafsir Muyassar dan tafsir-tafisr lainnya, menyatakan : Ringkasannya, para malaikat Allah yang tidak menyalahi perintah-Nya dan tidak pernah mendurhakai atau berdosa kepada Allah, mereka selalu taat dan patuh apabila diperintah oleh Allah maka mereka segera mengerjakannya tanpa terlambat barang sekejap pun, dan memiliki kemampuan untuk mengerjakannya.

Sehubungan dengan hal tersebut di atas yang telah dipaparkan oleh para Mufassir tentang tanggung jawab orang tua terhadap pendidikan akhlak anak berdasarkan Al-Qur'an surat At-Tahrim: 6 yaitu pentingnya taat dan patuh kepada Allah, selalu berzikir kepadanya dan melarang anak dari perbuatan tercela yakni didik dan ajarilah pada diri anak dalam masalah ketauhidan dan ilmu akhlak, terutama mendidik agar terbiasa melakukan dan mendirikan shalat, karena dengan shalat dapat mencegah manusia dari perbuatan keji dan munkar. Pendidikan ketauhidan dan ilmu akhlak harus diberikan pada keluarga atau anak berguna untuk mendapatkan kebahagiaan dan keselamatan hidup di dunia dan akhirat.

\section{PENUTUP}

Tanggung jawab orang tua dalam pendidikan akhlak anak yang sangat penting sekali adalah anak diajarkan hal-hal yang telah difardukan Allah SWT dan sesuatu hal yang harus di jauhi sebagaimana Allah telah melarangnya. Orang tua mempunyai peranan dan tanggung jawab yang harus dipenuhi dalam memelihara anaknya, jika orang tua tidak bertanggung jawab, tidak memelihara anaknya dan tidak membawa keluarganya kepada hal - hal yang baik dengan nasehat dan pelajaran maka dengan kemungkinan, dalam kehidupan keluarga tidak akan mendapatkan kebahagiaan dan keselamatan, dan sungguh Allah akan memberikan azab, berarti dia (orang tua) termasuk orang-orang yang zalim. 
Tanggung jawab orang tua terhadap pendidikan akhlak anak berdasarkan Al-Qur'an surat At-Tahrim: 6 yaitu pentingnya taat dan patuh kepada Allah, selalu berzikir kepadanya dan melarang anak dari perbuatan tercela yakni didik dan ajarilah pada diri anak dalam masalah ketauhidan dan ilmu akhlak, terutama mendidik agar terbiasa melakukan dan mendirikan shalat, karena dengan shalat dapat mencegah manusia dari perbuatan keji dan munkar. Pendidikan ketauhidan dan ilmu akhlak harus diberikan pada keluarga atau anak berguna untuk mendapatkan kebahagiaan dan keselamatan hidup di dunia dan akhirat.

Betapa besar peranan orang tua dalam mendidik akhlak anak yang akan sangat berpengaruh terhadap lingkungan social kemasyarakatan. Dengan demikian dapat ditarik kesimpulan bahwa peranan orang tua adalah mendidik dan mengajarkan dari berbagai ilmu pengetahuan yang sesuai dengan pendidikan Islam untuk menjadikan anak yang shaleh dan shalehah dan untuk membangun kepribadian anak sehat, cerdas dan terampil kelak dewasa hingga mampu bersaing di masa datang.

\section{REFERENSI}

'Aidh Alqarni, Dr. Tafsir Muyassar, Qisthi Press, Jakarta, 2008

Al Hasyimi Ahmad Sayyid. Kitab Mukhtar Al Hadist An Nabawiyyah. Al Alawiyyah. Semarang

Al Maraghi Musthafa Ahmad. 1993. Tafsir Al Maraghi. PT. Karya Toha Putra. Semarang

Al Imam Abdul Fida Ismail Ibnu Kasir AD Dimasyqi. 2008. Tafsir Ibnu Kasir. Sinar Baru Al Gensindo. Bandung

Anwar Dr, Pendidikan Anaka Usia Dini, Alfabeta, Bandung, 2007

Arikunto Suharsimi, Prof. Dr. 2006. Prosedur Penelitian. Rineka Cipta. Jakarta

Departemen Agama Rl, Al-Qur'an dan Tafsirnya, PT. Dana Bhakti Wakap, Yogyakarta, 1995

Departemen Agama RI. Al Qur'an dan Terjemahnya. PT. Dana Bhakti Wakap, Yogyakarta, 1971

Djumariah Syaiful Bahri, Drs dan Aswan Zain, Drs. 2006. Strategi Belajar Mengajar. Rineka Cipta. Jakarta 
Abdurrahman, Drs., M.Ag. 2007. Meaningful Learning Re Invensi Kebermaknaan Pembelajaran. Pustaka Pelajar. Yogyakarta

Idrus Fahmi, Drs. Kamus Lengkap Bahasa Indonesia. Greisinda Press. Surabaya

Jalaludin Rakhmat, Catatan Kang Jalal Visi Media, Politik dan Pendidikan, Remaja Rosda Karya, Bandung, 1997

Kusnadi Dede, Drs.,M.Pd.I. 2008. Diktat Metode Penelitian. Fakultas Agama Islam UNSIKA. Karawang

Lee Salk, Keinginan Anak-anak yang Perlu Diketahui Orang Tua, Apollo, Bandung, 197

Mansyur Yakhsyallah, Drs. 2008. Tanggung Jawab Orang Tua Dalam Pendidikan Anak.

Sahlan Syafe'l, Bagaimana Anda Mendidik Anak, Ghalia Indonesia, CV. Andes Utama Prima, 1994

Sardiman, Interaksi dan Motivasi Belajar Mengajar, Raja Grafindo Persada, Jakarta, 2004

Syeh Imam Al Qurtubi. Tafsir Al Qurtubi, Pustaka Azzam, Jakarta, 2009

Syekh Ahmad Showi Al Maliki. Tafsir Jalalaini. Daru Ihyail Kitab Al Arabiyyah. Indonesia

Taqiyudin, Pendidikan Untuk Semua, Mulia Press, Bandung, 2008.

UU RI Nomor 20 Tahun 2003, Sistem Pendidikan Nasional, Asa Mandiri, Jakarta, 2008

Zainudin, Anak dan Lingkungan Menurut Pandangan Islam, CV Andes Utama Prima, 1994

Zuhairini, Dra, dkk. Filsafat Pendidikan Islam. Bumi Aksara. Jakarta. 1993. 
ACHMAD JUNAEDI SITIKA DAN INE NIRMALA

136 | AL HIKMAH: INDONESIAN JOURNAL OF EARLY CHILDHOOD ISLAMIC EDUCATION | VOL.1 (2), 2017 